Second chance

Last week, Europe's Orbital Test Satellite was destroyed shortly after launch. Judy Redfearn reports

Europe's hope for a sophisticated system of communications satellites by the early 1980 s might well have gone up in a cloud of smoke with the European Space Agency's (ESA) Orbital Test Satellite (OTS) last week, had it not been for ESA's foresight. In the wake of two mishaps by NASA earlier this year-its failure to launch Geos into the correct geostationary orbit and an accident with a Delta launcher which meant that OTS could not be launched in June as plannedESA made sure that it went ahead with a plan to take out insurance cover for the launch of OTS and the integration of a second flight model. The insurance, to the tune of $\$ 29$ million at a premium of about $\$ 2$ million, was placed by Bowring of London throughout all the countries taking part in the project in proportion to their financial commitment to it.

As fate would have it, ESA's precaution was extremely wise. Seven miles above Cape Canaveral's main launch pad and only $54 \mathrm{~s}$ after a seemingly perfect launch, the Delta 3914 carrying OTS began to disintegrate and exploded just prior to a signal of destruction. The insurance cover, however, gives Europe another chance. As with all satellite missions, ESA built a second OTS identical to the first which could be ready for launch by next March. This means that the OTS test and experimental programme could still be compressed to be completed within the original time.

A second chance is particularly important for the OTS because, unlike Geos, it has considerable commercial potential. It is Europe's first communications satellite and is the forerunner of four similar satellites which are planned for launch by Ariane, Europe's own launcher which is still being developed, between 1981 and 1990. They will carry a large part of intra-European telephone, telegraph and telex traffic and will relay European television programmes. The OTS's task is to test much of the equipment which will be used on the operational satellites and to provide a pre-operational European traffic capacity.

The decision on whether or not to go ahead with the second OTS launch early next year will probably be taken by ESA officials this week. As the only launcher available to do the job is the American Delta 3914, they are probably hoping for some assurance from the Americans that a similar accident is extremely unlikely to happen again. Although the success rate of Delta launchers is very good-134 have been launched since 1966, 122 of them successfully - the history of the Delta 3914 is not so happy. Three of them have been launched and the OTS marks the first failure: but the launcher which was damaged in May this year and caused a three-month delay to the OTS programme was also a 3914. In that case, one of the booster rockets fell off the main Delta vehicle because of a defective bolt.

Late last week, NASA set up a seven member team of inquiry to look into the incident. It hopes to find out whether or not the fault lay in the basic Delta vehicle or the attached rockets before 13 October, the planned launch date of the International Sun-Earth Explorer (ISEE) in which ESA has a large interest. If the fault is found in the Delta 3914's strap-on rockets then it should be safe for the ISEE to go ahead as planned as the Delta 2914, on which it will be launched, uses a different rocket configuration.

Until late 1980 when the Ariane launcher is ready for use, ESA will have to launch its satellites on US vehicles. By the early 1980s, however, there may be another option if a West German company, Orbital Transport-und Raketen-Aktiengesellschaft (OTRAG), is successful in developing its own heavy launch vehicle. So far, it has spent $\$ 30$ million on the project and hopes by 1981 to be launching satellites from Zaire. ESA will not discuss the possibilty of using OTRAG launchers until it knows whether they, and Ariane, will work.

\title{
BRITAIN
}

\section{Timely delay}

The Council for Science and Society has recently published a report called The Acceptability of Risks. Alastair Hay reports

IN spite of a 12-month delay, the Council for Science and Society's report, The Acceptability of Risks* published last week has arrived at an opportune moment: the exlosion at Flixborough, and the release of tetrachlorodibenzo-p-dioxin at Séveso are recent memories, and the public enquiry at Windscale is still in progress. Its findings and recommendations will certainly provoke heated debate.

Risks, it claims, are very unevenly distributed; those in the UK at greatest risk are "concentrated in the homes,

*The Acceptability of Risk is available from Barry Rose (Publishers) Limited, Little London, Chichester, Sussex, $£ 5.00$. communities and workplaces of manual workers and their families". In a harsh message, the report states that positive action to remove this inequality is urgently needed, and that it regrets that "hazards of all sorts have been shamefully neglected in scientific and technological research".

The report also points out the potential danger of regulatory agencies being weakened and rendered ineffective by financial constraints and inappropriate standards. Indiscriminate use of the terms 'safe' and 'acceptable' are to be avoided, it says, as both are ambiguous and subject to a wide range of individual interpretation.

Appendices deal with specific issues such as nuclear radiation, ammunition and explosives, the hazards of asbestos, and the Flixborough Court of Enquiry. In a disturbing commentary on the conduct of the Flixborough court investigation, one of the authors of the report, Brigadier R. L. Allen, claims that the enquiry was too narrow; that some relevant evidence was not considered; and that statements by the court to the effect that "Nypro [owners of the Flixborough plant] were safety conscious" were inappropriate in the light of the evidence presented. He says that this is illustrated by Nypro's breach of licensing arrangements when it stored 43 times more inflammable fluid on site than it was entitled to do: a fact which severely hindered rescue operations after the initial explosion.

In conclusion, the report recommends areas of investigation to be considered by working groups and which could provide useful information for 'risk management' in the future. Also suggested is the possibility of the appointment of 'risk advisers' in particular occupations and localities.

A few of the abuses the report refers to have been dealt with during its delay at the printers. Few will consider this more than a minor fault. 